\title{
RASSF7 Gene
}

National Cancer Institute

\section{Source}

National Cancer Institute. RASSF7 Gene. NCI Thesaurus. Code C158516.

This gene plays a role in the negative regulation of stress-induced apoptosis. 